\title{
Program Aktif (Aku Positif) untuk Meningkatkan Harga Diri Menjelang Masa Bebas pada Anak Didik di Lembaga Pembinaan Khusus Anak (LPKA)
}

\author{
Aktif (Aku Positif) Program to Improve Self-esteem \\ of Juvenile Delinquent Before Departure Day in Youth Detention Center
}

Fany Fakhrah ${ }^{1}$ Esti Hayu Purnamaningsih ${ }^{1}$

1,2Fakultas Psikologi, Universitas Gadjah Mada

\begin{abstract}
Bad perception from public towards inmates can negatively impact their selfperception during their induction time. They may suffer from low self-esteem in facing public acceptance when they are released from the detention center. This study employed AKTIF (Aku Positif) program that aimed to boost self-esteem of juvenile delinquent at the end of their detention. The study applied untreated control group with dependent pretest and posttest samples design. Wilcoxon non parametric statistical test was used as data analysis method in this study. Twelve adolescents (age 16-18 years old) are subject. The result of this study showed that there was a significant increase of the Rosenberg self-esteem score from the experiment group $\mathrm{U}(\mathrm{n}=6)=0.027, \mathrm{p}<0.05$ after the end of AKTIF program. The study showed that AKTIF program is proven to be effective on increasing juvenile delinquent's self-esteem at the end of their detention period.
\end{abstract}

Keywords: adolescent; AKTIF program; juvenile delinquent; self-esteem; youth detention center

Abstrak. Persepsi masyarakat tentang narapidana memberikan efek yang buruk terhadap persepsi narapidana tentang diri mereka sehingga tahanan anak merasa rendah diri menghadapi penerimaan masyarakat setelah masa hukuman berakhir. Penelitian ini menggunakan Program AKTIF (Aku Positif) yang bertujuan untuk meningkatkan harga diri remaja yang berhadapan dengan hukum menjelang masa bebas. Desain yang digunakan dalam penelitian ini adalah untreated control group design with dependent pretest and posttest samples. Analisis data yang digunakan dalam penelitian ini adalah uji statistik non parametrik Wilcoxon. Subjek penelitian berjumlah 12 orang remaja yang sedang menjalani masa tahanan (usia 16-18 tahun). Hasil penelitian menunjukkan bahwa terdapat peningkatan skor self-esteem lebih tinggi $U(n=6)=0,027, p<0,05$ secara signifikan pada kelompok eksperimen. Hasil penelitian ini menunjukkan bahwa program AKTIF (Aku Positif) terbukti efektif dalam meningkatkan harga diri pada anak didik di lembaga pemasyarakatan untuk mempersiapkan diri menjelang masa bebas.

Kata kunci: harga diri; lembaga pembinaan khusus anak (LPKA); program AKTIF; remaja; tahanan anak

${ }^{1}$ Korespondensi mengenai artikel ini dapat dilakukan melalui fakhrahfany@gmail.com

2atau esti@ugm.ac.id 
Kasus kriminalitas pada remaja merupakan salah satu akibat dari keingintahuan dan keinginan mereka agar diakui keberadaannya sebagai proses pencarian jati diri. Akibatnya tidak sedikit remaja harus mendekam di penjara untuk mempertanggungjawabkan perbuatannya. Terkait dengan harga diri, lingkungan lembaga pemasyarakatan (LAPAS) yang penuh dengan stigma dan tekanan bisa menjadi pemicu semakin rendahnya harga diri dan gangguan psikologis lainnya pada individu yang berada didalamnya (Utami \& Asih, 2016), terlebih pada remaja yang harus berhadapan dengan hukum. Harga diri sendiri telah lama diduga berhubungan dengan penyebab seseorang melakukan kejahatan (Akhyar, 2014).

Fenomena yang berkembang dalam masyarakat pada saat ini adalahkurang diterimanya mantan narapidana untuk kembali hidup bersama di masyarakat. Anggapan masyarakat bahwa narapidana yang telah berada di rumah tahanan masih mempunyai kecenderungan kuat untuk menjadi residivis. Fenomena perlakuan diskriminatif tersebut mengakibatkan dampak yang kurang baik bagi mantan narapidana karena merasa tertekan dan mempunyai beban moral yang berat sehingga mereka akan cenderung untuk kembali melakukan tindak kejahatan yang pernah dilakukannya (Akhyar, 2014).

Harga diri yang dimiliki seseorang akan menentukan bagaimana ia menampilkan dirinya di lingkungan. Harga diri sendiri merupakan salah satu komponen yang lebih spesifik dari konsep diri yang melibatkan unsur evaluasi atau penilaian terhadap diri (Robinson, Shaver, \& Lawrence, 1991; Aditomo \& Retnowati,
2004). Pemenuhan kebutuhan harga diri individu, khususnya pada kalangan remaja sangatlah penting. Hal ini berkaitan dengan dampak negatif apabila remaja memiliki harga diri yang rendah. Remaja akan kesulitan dalam menampilkan perilaku sosialnya, merasa inferior dan canggung (Harter, 1990; Larson, 2000). Tidak hanya itu, harga diri yang rendah dapat menjadi penyebab masalah depresi dan kenakalan remaja (Harter, 1990; Larson, 2000).

Dalam dunia remaja, harga diri dianggap sebagai faktor penting. Coopersmith (1967) mengemukakan bahwa kenakalan yang dilakukan oleh remaja disebabkan karena mengalami kegagalan dalam memperoleh penghargaan diri dari masyarakat. Mereka akan melakukan kompensasi dengan tindakan lain yang seolah-olah membuatnya menjadi lebih berharga. Dari sana kemudian muncul perilaku penyalahgunaan obat-obatan, perkelahian, tawuran, yang dilakukan untuk mendapatkan pengakuan dari lingkungan. Perilaku-perilaku yang dilakukan tersebut dalam kategori kenakalan remaja akan ditangani secara hukum.

Untuk mengurangi masalah remaja yang terkait dengan harga diri, seorang remaja perlu berfokus pada pengembangan harga diri. Meningkatkan harga diri dilakukan dengan berpikir positif mengenai sumber daya personal, seperti kemampuan berpikir mengenai prestasi yang telah dicapai, kemampuan spesifik yang dimiliki, tujuan dan inisiatif (Harter, 1990; Larson, 2000). Deskripsi harga diri sendiri didasarkan pada tiga aspek, yaitu perasaan mengenal diri sendiri, perasaan mengenai kehidupan, dan perasaan mengenai 
perasaan mengenai hubungan dengan orang lain (Brander, 1993; Minchiton, 1995; Dogson \& Wood, 1998; Anggraeni, Sugiarti, \& Christia, 2010).

Di Indonesia, penanganan psikologis pada remaja dalam lembaga pembinaan masih jarang, khususnya pemberian intervensi untuk meningkatkan harga diri remaja. Salah satu upaya yang akan dilakukan adalah pemberian Program AKTIF (Aku Positif). Program AKTIF (Aku Positif) merupakan pengembangan dari psikoterapi positif diketahui mampu meningkatkan harga diri sehingga diharapkan program ini dapat menjadi salah satu layanan support bagi tahanan anak dalam meningkatkan harga diri untuk membantu mempersiapkan diri menghadapi masa bebas dari lembaga pembinaan khusus anak (LPKA). Hal tersebut dibuktikan dalam penelitian yang dilakukan oleh Cerezo, Ortiz-Tallo, Cardenal dan de la Torre-Luque (2014) jika psikoterapi positif mampu meningkatkan kekuatan positif individu termasuk harga diri pada individu. Penelitian tersebut menggunakan psikologi positif sebagai acuan dalam mengenali diri individu untuk mengasah kemampuan dalam mengenali, memahami dan mengapresiasi diri.

Tujuan yang ingin dicapai dalam penelitian ini adalah memperoleh gambaran harga diri pada anak didik dalam lembaga pembinaan khusus anak (LPKA) dan melihat pengaruh Program AKTIF (Aku Positif) untuk meningkatkan harga diri pada anak didik. Di Indonesia belum banyak penelitian yang dilakukan untuk meningkatkan harga diri khususnya pada anak didik di lembaga pembinaan yang berfokus pada persiapan masa bebasnya.
Beberapa penelitian sebelumnya hanya berfokus untuk menurunkan kecemasan dan stres menjelang bebas sedangkan kehidupan baru remaja akan dimulai sejak ia bebas dari tahanan sehingga pemberian program ini diharapkan dapat membantu remaja membangun harga diri yang baik sekaligus menjadi usaha preventif untuk mencegah remaja mengulangi perilaku negatifnya ketika telah kembali tengah masyarakat. Penelitian ini diharapkan dapat membantu menjadi acuan atau literatur bagi pembaca dan masyarakat terkait dengan harga diri pada remaja yang berada di lembaga pembinaan khusus anak (LPKA). Penelitian ini juga diharapkan menjadi salah satu alternatif intervensi dalam membantu meningkatkan harga diri pada remaja yang berada di lembaga pembinaan khusus anak (LPKA) untuk mempersiapkan mereka bebas dari tahanan. Hasil penelitian ini diharapkan juga dapat digunakan sebagai informasi yang bermanfaat bagi peneliti selanjutnya, praktisi, aktivis sosial dan staf lembaga pembinaan khusus anak dalam mendampingi remaja, khususnya pada remaja yang terlibat dengan hukum.

\section{Metode}

Penelitian ini menggunakan variabel harga diri sebagai variabel tergantung atau dependen. Sementara itu, Program AKTIF (Aku Positif) sebagai variabel terikat atau independen. Subjek dalam penelitian ini berjumlah 12 orang remaja (usia 16-18 tahun) yakni 6 orang remaja pada kelompok eksperimen dan 6 orang remaja pada kelompok kontrol yang sedang menjalani masa pembinaan di LPKA 
dengan pendidikan terakhir SD (Mampu baca tulis), semua peserta yang terlibat berjenis kelamin laki-laki, tidak ada batasan jenis kelamin dalam penelitian namun berdasarkan hasil pemilihan secara acak, jumlah tahanan perempuan sangat sedikit serta tidak memenuhi kriteria penelitian yang lain. Selain itu peserta yang terlibat dipastikan telah melewati masa karantina, telah menjalani tiga per empat masa tahanan, memiliki sisa masa tahanan tidak kurang dari 3 bulan, dan memiliki latar belakang kasus yang beragam.

\section{Modul Program AKTIF (Aku Positif)}

Intervensi dalam penelitian ini dilakukan berdasarkan Modul Program AKTIF (Aku Positif). Modul tersebut merupakan hasil modifikasi dari modul psikoterapi positif yang telah disusun oleh Retnowati, Anjarsari, Wibowo dan Tanau (2015). Modul Program AKTIF (Aku Positif) telah melalui analisis uji validasi modul nilai Aiken's $V$ dengan nilai rerata 0,83 dengan kesepakatan antar rater sebesar 0,96.

Adapun gambaran sesi yang terdapat dalam Program AKTIF (Aku Positif), yaitu 1) Menggunakan kekuatan terbaik dalam diri (using your strength); 2) Menemukan tiga hal baik/berkah dalam hidup (three good things); 3) Membuat biografi terbaik untuk dikenal (life summary); 4) Mengungkapkan terima kasih (The Gratitude Visit); 5) Merespons orang lain (Active Constructive Responding); dan 6) Menikmati sesuatu dengan menyenangkan (Savoring). Terdapat beberapa manfaat dari penerapan Program AKTIF (Aku Positif) ini seperti menurunkan simtom-simtom distress, kecemasan, depresi secara signifikan sekaligus menguatkan harga diri, efikasi diri dan optimisme.
Intervensi yang diberikan akan dilakukan secara berkelompok. Intervensi Program AKTIF (Aku Positif) diberikan oleh 1 orang fasilitator, 2 orang kofasilitator dan orang observer. Fasilitator dari Program AKTIF (Aku Positif) merupakan seorang psikolog, lulusan Magister Profesi Psikologi, Memahami dinamika psikologis remaja, Memiliki pengalaman sebagai konselor bagi remaja, dan berpengalaman memberikan pelatihan kepada remaja. Co-faclitator dalam Program AKTIF (Aku Positif) merupakan lulusan atau mahasiswa magister profesi psikologi yang telah menyelesaikan ujian praktik profesi psikologi dan memiliki pengalaman sebagai konselor bagi remaja. Observer merupakan mahasiswa S-1/S-2 psikologi yang telah mendapatkan mata kuliah observer.

\section{Instrumen penelitian}

Selain modul intervensi, terdapat beberapa instrumen yang digunakan di dalam penelitian ini, seperti: 1) lembar observasi, 2) Rosenberg Self-esteem Scale (SEI), 3) Positive Psychotherapy Inventory (PPTI), 4) buku penugasan, 5) informed consent, dan 6) lembar presensi. Lembar observasi dalam penelitian ini digunakan untuk memperoleh gambaran kondisi subjek selama penelitian berlangsung. Hasil observasi diolah bersama hasil dari buku penugasan subjek selama penelitian yang akan dianalisis secara kualitatif. Analisis kualitatif dilakukan agar peneliti dapat memahami proses dan kemajuan subjek secara lebih komprehensif.

$$
\text { Rosenberg Self Esteem Scale (SEI) }
$$
memiliki nilai koefisien reliabilitas 0,764 dengan corrected item total berkisar antara 
0,286-0,544 sehingga layak digunakan sebagai instrumen alat ukur harga diri. Positive psychotherapy inventory (PPTI), Skala PPTI telah diuji cobakan pada penelitian sebelumnya. Dari hasil tersebut diperoleh hasil konsistensi internal yang tinggi $\left(\alpha=0,93 ; \quad r_{i x}>0,3\right)$ dengan indeks korelasi aitem total bergerak dari 0,43 hingga 0,69. Buku penugasan peserta merupakan lembar kerja yang akan digunakan oleh peserta selama mengikuti program. Informed consent merupakan pernyataan persetujuan dari individu yang akan menjalani proses di bidang psikologi yang meliputi penelitian pendidikan/pelatihan/asesmen dan intervensi psikologi. Lembar presensi digunakan untuk memonitor daftar hadir dalam semua sesi pelatihan bagi semua pihak yang terlibat di dalam penelitian.

Tabel 1.

Statistik Deskriptif Skor Self Esteem

\begin{tabular}{llllllc}
\hline Kelompok & Pengukuran & $N$ & Min & Max & Mean & Std.deviation \\
\hline Kelompok eksperimen & Pretest & 6 & 20 & 24 & 21,66 & 1,50 \\
& Posttest & 6 & 22 & 27 & 25,33 & 1,75 \\
Kelompok kontrol & Pretest & 6 & 21 & 22 & 22,66 & 1,03 \\
& Posttest & 6 & 22 & 30 & 25 & 3,34 \\
\hline
\end{tabular}

\section{Analisis data}

Metode yang digunakan dalam penelitian ini adalah pendekatan kuantitatif dengan desain kuasi eksperimen the untreated control group with pretest and posttest. Adapun analisis yang digunakan adalah analisis data kuantitatif melalui uji non parametrik Mann-Whitney untuk menganalisis perbedaan skor antara kelompok kontrol dan kelompok eksperimen serta analisis uji Wilcoxon untuk mengetahui perbedaan skor pada kelompok eksperimen saat sebelum dan setelah pemberian intervensi. Penelitian menggunakan partisipan berjumlah kurang dari 30 orang sehingga belum memenuhi prasyarat pengujian hipotesis dengan menggunakan analisis uji parametrik (Azwar, 2017).

\section{Hasil}

Berdasarkan tabel 1 diketahui bahwa pada kelompok eksperimen, terjadi peningkatan rerata skor self-esteem dari sebelum (pretest) dan setelah (posttest) sebesar 3,67 poin. Rerata skor self-esteem pada kelompok kontrol juga menunjukkan peningkatan dari Pretest ke posttest dengan selisih 2,34 poin. Adapun manipulation check dilakukan dengan menggunakan skala PPTI. Tabel 2 menunjukkan gambaran data statisitik deskriptif skor PPTI pada kedua kelompok.

Berdasarkan tabel 2 diketahui bahwa pada kelompok eksperimen, terjadi peningkatan rerata skor PPTI dari sebelum (pretest) dan setelah (posttest) sebesar 7,67 poin. Rerata skor self-esteem pada kelompok kontrol juga menunjukkan peningkatan dari pretest ke posttest dengan selisih poin 2 poin. 
Tabel 2.

Statistik Deskriptif Skor Skala PPTI

\begin{tabular}{llllllc}
\hline Kelompok & Pengukuran & N & Min & Max & Mean & Std.deviation \\
\hline Kelompok eksperimen & Pretest & 6 & 19 & 33 & 26 & 6,44 \\
& Posttest & 6 & 24 & 39 & 33,67 & 5,42 \\
Kelompok kontrol & Pretest & 6 & 23 & 31 & 3,08 & 3,08 \\
& Posttest & 6 & 33 & 39 & 5,08 & 5,08 \\
\hline
\end{tabular}

Hasil uji statistik menunjukkan adanya perbedaan signifikan pada skor self-esteem antara kelompok eksperimen $U(n=12)=6,000 ; \quad p=0,048, \quad p<0,05 \quad$ pada kelompok eksperimen $(M=8,50)$ dengan kelompok kontrol $(M=4,50)$ dengan effect size sebesar $35 \%$. Hal ini menunjukkan bahwa program AKTIF (Aku Positif) mampu memberikan pengaruh secara efektif dalam meningkatkan harga diri pada remaja di dalam lembaga pemasyarakatan. Lebih lanjut, peneliti juga melakukan analisis tambahan melalui uji analisis Wilcoxon untuk mengetahui perbedaan skor yang signifikan pada kelompok eksperimen sebelum dan setelah diberikan perlakuan.

Berdasarkan ringkasan hasil uji Wilcoxon, disimpulkan bahwa terdapat perbedaan skor yang signifikan pada skor harga diri sebelum dan sesudah intervensi diberikan pada kelompok eksperimen. Hasil data tersebut menunjukkan bahwa Program AKTIF (Aku Positif) memberikan effect size (sumbangan efektif) sebesar $64 \%$ terhadap peningkatan harga diri pada remaja di dalam lembaga pemasyarakatan.

Hasil analisis Mann-Whitney terhadap skor PPTI menunjukkan $U(n=12)=0,68, \quad p<0,05) \quad$ pada kelompok eksperimen $(M=6,08)$ dibanding dengan kelompok kontrol $(M=6,92)$ dengan effect size sebesar 0,01 yang menunjukkan bahwa tidak terdapat perbedaan yang signifikan sebelum dan setelah diberikan Program AKTIF (Aku Positif) antara kelompok eksperimen maupun kelompok kontrol. Sama halnya pada pengukuran self-esteem, Peneliti juga melakukan analisis tambahan melalui uji analisis Wilcoxon untuk mengetahui perbedaan skor PPTI yang signifikan pada kelompok eksperimen sebelum dan setelah diberikan perlakuan.

Berdasarkan ringkasan hasil uji Wilcoxon pada skor PPTI, disimpulkan bahwa terdapat perbedaan skor yang signifikan pada skor harga diri sebelum (pretest) dan sesudah (posttest) intervensi diberikan pada kelompok eksperimen. Data tersebut menunjukkan bahwa tidak terdapat peningkatan pada skor harga diri yang terjadi pada 3 partisipan.

\section{Diskusi}

Program Aktif (Aku Positif) bertujuan untuk membantu meningkatkan harga diri pada anak didik menjelang masa bebas. Berdasarkan hasil analisis data menunjukkan adanya perbedaan yang signifikan pada harga diri anak didik yang mengikuti Program AKTIF (Aku Positif). Hal ini mendukung penelitian sebelumnya yang dilakukan oleh Cerezo dan koleganya (2014) jika psikoterapi positif mampu meningkatkan kekuatan positif individu 
termasuk harga diri pada individu. Penelitian tersebut menggunakan psikologi positif sebagai acuan dalam mengenali diri individu untuk mengasah kemampuan dalam mengenali, memahami dan mengapresiasi diri.

Tidak hanya itu, hasil penelitian juga menunjukkan adanya peningkatan skor kelompok eksperimen dan kelompok kontrol. Meskipun hasil penelitian menunjukkan adanya peningkatan secara signifikan, akan tetapi berdasarkan data kuantitatif peningkatan skor harga diri dan PPTI tidak hanya terjadi pada kelompok eksperimen namun juga pada kelompok kontrol. Pada penelitian eksperimen, kondisi ini mungkin saja terjadi disebabkan oleh experimental treatment diffusion, yaitu suatu kondisi saat kelompok kontrol belajar dari kelompok eksperimen, baik disengaja maupun tidak. Disebabkan karena partisipan dalam kelompok kontrol dan kelompok eksperimen berasal dari LPKA yang sama. Tidak hanya itu, peluang terjadinya faktor eror seperti pengerjaan secara asal, adanya proses maturity pada partisipan dalam kelompok kontrol juga bisa terjadi yang kemudian berpengaruh pada hasil pengukuran. Adanya ancaman validitas internal mungkin terjadi saat pelaksanaan intervensi seperti kondisi partisipan sesaat sebelum mengikuti sesi yang tidak dapat dikontrol oleh peneliti.

Di sisi lain, dinamika setiap partisipan menunjukkan adanya kondisi yang memengaruhi perubahan partisipan. Pada perbandingan gain score pada pengukuran saat pretest, posttest dan follow up partisipan terlihat jika terdapat pengurangan skor pada 2 orang partisipan pada masa follow up. Hal ini mungkin saja terjadi karena kedua partisipan sedang berada dalam kondisi di mana mereka telah memasuki masa untuk dipindahkan ke lembaga pemasyarakatan (Lapas) dewasa. Hal tersebut tentu saja memicu munculnya kekhawatiran yang baru bagi partisipan. Adanya kekhawatiran tersebut dianggap normal pada individu sehingga dapat memengaruhi kondisi psikologis partisipan. Di mana tingkah laku penyesuaian diri terhadap lingkungan diawali dengan stres, yaitu suatu keadaan diri ketika lingkungan bisa mengancam kesejahteraan atau kenyamanan diri (Baum, 1991; Sarwono, 1994).

Untuk melihat seberapa efektif Program AKTIF (Aku Positif) dalam meningkatkan tingkat harga diri pada tahanan didik yang akan segera bebas dan kembali ke masyarakat digunakan teknik effect size. Berdasarkan hasil pengukuran didapatkan nilai effect size sebesar $64 \%$. Hal ini berarti Program AKTIF (Aku Positif) memiliki sumbangan efektif untuk meningkatkan harga diri pada anak didik menjelang masa bebasnya.

Hasil ini juga didukung oleh keunggulan dari Program AKTIF (Aku Positif) yang didasarkan pada konstruk teori psikoterapi positif di mana materi dan latihan yang diberikan dapat meningkatkan pemahaman dan pengertian subjek mengenai pentingnya mengenal kekuatan di dalam diri dan bagaimana cara mengoptimalkannya, memberikan kesempatan kepada partisipan untuk lebih bersyukur dan fokus akan hal-hal yang baik, serta bagaimana cara menggunakan semua hal positif tersebut untuk diri sendiri maupun orang lain (Sartika, 2018). 
Selain keunggulan Program AKTIF (Aku Positif), pemberian intervensi secara berkelompok juga mendukung keefektifan program ini. Pendekatan secara berkelompok tersebut dinilai baik digunakan dalam proses intervensi. Dalam pendekatan kelompok, partisipan dilibatkan dan dituntut untuk berlatih berargumentasi dan berdiskusi dengan teman kelompok sehingga membantunya membangun keterbukaan dan kepercayaan dengan sesama partisipan. Pendekatan kelompok dapat membantu peserta pelatihan untuk memahami materi melalui diskusi, mendapatkan kesempatan untuk saling memberi umpan balik, sehingga keyakinan, pengertian, kepercayaan dan harga diri dapat meningkat (Yalom \& Leszcz, 2005; Zulni, 2018).

Memiliki persepsi yang positif terhadap diri, akan membantu anak didik lebih siap menghadapi masa bebasnya. Dalam penelitian ini peningkatan harga diri terjadi pada semua partisipan penelitian setelah program diberikan. Program AKTIF (Aku Positif) memiliki sesi-sesi pertemuan yang membantu partisipan untuk menemukan dan menggunakan kekuatan terbaik dalam dirinya. Hal lain yang turut menyumbang keberhasilan program yaitu latihan-latihan dalam buku penugasan. Adanya perubahan skor partisipan menunjukkan bahwa adanya proses belajar selama proses intervensi berlangsung. Pembentukan dan perubahan sikap dalam psikologi diterangkan sebagai proses belajar atau sebagai proses kesadaran (kognisi). Dalam proses belajar, yang menjadi fokus adalah adanya rangsangan dari luar dan dalam teori proses kognisi adalah adanya dorongan atau kehendak dari dalam diri individu sendiri (Sarwono, 1994). Berdasarkan penjabaran tersebut, maka diketahui bahwa subjek yang mendapatkan Program AKTIF (Aku Positif) mengalami peningkatan harga diri dalam mempersiapkan dirinya untuk lebih siap menghadapi masa bebas.

Tingkah laku penyesuaian diri terhadap lingkungan diawali dengan stres, yaitu suatu keadaan diri ketika lingkungan mengancam kesejahteraan atau kenyamanan seseorang (Baum, 1991; Sarwono, 1994). Oleh karena itu, Perlunya pembekalan dan persiapan bagi remaja yang menjalani masa pembinaan untuk kembali ke tengah masyarakat dianggap penting karena remaja harus kembali memulai penyesuaian diri kembali dengan lingkungannya terdahulu. Berhasilnya penanganan bukan saja memberi harapan namun juga menemukan kemampuan potensial remaja sebagai sumber daya manusia muda (Zulni, 2018).

Penelitian ini tidak terlepas dari adanya keterbatasan. Adapun keterbatasan dalam penelitian ini adalah jumlah partisipan yang terlibat yakni hanya 12 orang sehingga hasil penelitian ini tidak dapat digeneralisasikan bagi seluruh remaja yang sedang menjalani masa pembinaan. Tidak hanya itu, partisipan yang terlibat dalam penelitian ini seluruhnya berjenis kelamin laki-laki. Sehingga peneliti tidak dapat membandingkan efektivitas program ini apabila diberikan kepada partisipan yang berjenis kelamin perempuan. Tidak hanya itu, adanya variabel-variabel extraneous yang mungkin muncul dan memengaruhi hasil penelitian sehingga persiapan matang perlu dilakukan sebelum penelitian. 


\section{Kesimpulan}

Hasil penelitian menunjukkan bahwa Program AKTIF (Aku Positif) dapat meningkatkan harga diri pada tahanan anak menjelang masa kebebasan sesaat setelah program diberikan. Hal tersebut didukung dengan adanya peningkatan skor harga diri pada partisipan penelitian sebelum dan setelah intervensi diberikan. Peningkatan harga diri terjadi karena materi program yang mudah dipahami oleh partisipan, adanya keinginan untuk berubah menjadi lebih baik, dukungan dari sesama partisipan, dan peran fasilitator dalam menyajikan materi sehingga terbentuk kekuatan positif dalam diri partisipan. Partisipan merasakan manfaat dan perubahan positif yang dialami setelah intervensi antara lain memahami dan mengenali kekuatan positif yang dimiliki, lebih bersyukur atas kesempatan yang dimiliki untuk menjadi lebih baik, serta merasa lebih siap menghadapi masa bebas.

\section{Saran}

Penerapan Program AKTIF (Aku Positif) tergolong praktis dan mudah untuk diterapkan oleh psikolog dalam memberikan intervensi sehingga diharapkan dapat menjadikan program ini sebagai salah satu alternatif intervensi yang dapat ditujukan pada kasus klien remaja. Bagi peneliti selanjutnya diharapkan memperhatikan variabel-variabel extraneous yang mungkin muncul dan dapat memmengaruhi hasil penelitian, diharapkan dapat menambah jumlah partisipan agar hasil penelitian lebih komprehensif dan dapat digeneralisasikan, melibatkan partisipan terhadap kelompok yang berbeda (anak didik berjenis kelamin perempuan, maupun warga binaan dewasa di lembaga pemasyarakatan), serta memperhatikan waktu pemberian posttest setelah intervensi dengan asumsi perilaku individu tidak berubah dalam waktu cepat.

\section{Kepustakaan}

Aditomo, A., \& Retnowati, S. (2004). Perfeksionisme, harga diri, dan kecenderungan depresi pada remaja akhir. Jurnal Psikologi, 31(1), 1-14.

Akhyar, Z. (2014). Persepsi masyarakat terhadap mantan narapidana di Desa Benua Jingah Kecamatan Barabai Kabupaten Hulu Sungai Tengah. Jurnal Pendidikan Kewarganegaraan, 4(7), 545-557.

Anggraeni, A., Sugiarti, A. M., \& Christia, M. (2010). Gambaran self esteem pada pelaku residivisme: Studi pada residivis di Lembaga Pemasyarakatan Kelas I Cipinang. Indigenous: Jurnal Ilmiah Psikologi, 12(2), 115-125.

Azwar, S. (2017). Penyusunan skala psikologi. Yogyakarta: Pustaka Pelajar.

Baum, A. (1990). Stress, intrusive imagery, and chronic distress. Health Psychology, 9(6), 653-675. doi: $\underline{10.1037 / 0278-6133.9 .6 .653}$

Cerezo, M. C., Ortiz-Tallo, M., Cardenal, V., \& de la Torre-Luque, A. (2014). Positive psychology group intervention for breast cancer patients: A randomised trial. Psychological Reports, 115(1), 44-64. doi: $\underline{10.2466 / 15.20 . P R 0.115 \mathrm{c} 17 \mathrm{z} 7}$ 
Coopersmith. (1967). The antecedents of self esteem. San Fransisco: W.H. Freeman \& Company.

Harter, S. (1990). Self and identity development. In S. S. Feldman \& G. R. Elliott (Eds.), At the threshold: The developing adolescent (hal. 352-387). Harvard University Press.

Larson, R.W. (2000). Toward a psychology of positive youth development. American Psychologist Vol. 55, No. 1, 170-183. doi: 10.1037/0003066X.55.1.170

Minchinton, J. (1995). Maximum self-esteem: The handbook for reclaiming your sense of self-worth. Golden Books Centre.

Retnowati, S., Anjarsari, N., Wibowo, C., \& Tanau, M. (2015). Positive psychotherapy untuk mahasiswa (Manuskrip tidak dipublikasikan). Yogyakarta: Fakultas Psikologi Universitas Gadjah Mada.

Robinson, J. P., Shaver, P. R., \& Lawrence, S. W. (1991). Criteria for scale selection and evaluation. In J. P. Robinson, P. R. Shaver, \& S. W. Lawrence, Measures of Social Psychological Attitudes (hal.116). Academic Press.
Sartika, P.D,. (2018). Program Aktif (Aku Positif) untuk meningkatkan resiliensi pada remaja putri yang tinggal di panti asuhan (Tesis tidak dipublikasikan). Universitas Gadjah Mada, Yogyakarta.

Sarwono, W. S. (1994). Psikologi lingkungan. Jakarta: Grasindo.

Utami, R. R., \& Asih, M.K., (2016). Konsep diri dan rasa bersalah pada anak didik Lembaga Pemasyarakatan Anak Kelas IIA Kutoarjo. Indigenous: Jurnal Ilmiah Psikologi, 1(1), 84-91. doi: $\underline{10.23917 / \text { indigenous.v1i1.2214 }}$

Yalom, I., \& Leszcz, M. (2005). Theory and practice of group psychotherapy (Edisi kelima). Basic Books.

Zulni, L. (2018). Pelatihan Berpikir Positif untuk menurunkan kecemasan menghadapi masa bebas pada anak di Lembaga Pembinaan Khusus Anak Kutoarjo (Tesis tidak dipublikasikan). Universitas Gadjah Mada, Yogyakarta. 